\title{
Morphometry and immunohistochemistry of follicles growth and steroidogenesis in saharian wild sand rat, Psammomys obesus, ovary
}

\author{
Amina Boubekri' ${ }^{1}$, Thérese Gernigon-Spychalowicz' ${ }^{1}$, Farida Khammar1, \\ Jean-Marie Exbrayat ${ }^{2}$
}

${ }^{1}$ Université des Sciences et de la Technologie Houari Boumédiene, Faculté des Sciences Biologiques, Laboratoire de Recherche sur les Zones Arides. Bab Ezzouar 132 El Alia 16100 Algiers, Algeria

${ }^{2}$ Université de Lyon, Laboratoire de Biologie Générale, UCLy; Laboratoire de Reproduction et

Développement Comparé, E.P.H.E. 25, rue de Plat, 69288 Lyon, France.

\begin{abstract}
The sand rat (Psammomys obesus) constitutes a model to study seasonal changes and several metabolic disorders. In order to perform breeding laboratory conditions, the reproductive function of this species living in North Occidental Algerian Sahara was studied. The aim of this work was to investigate the follicular growth changes and the steroidogenic associated aspects. The study was performed using morphometrical and immunohistochemical methods. From primordial to preantral states, the follicle diameter increased progressively from 17-20 $\mu \mathrm{m}$ to $192-225 \mu \mathrm{m}$. The preovulatory follicles reached about $500 \mu \mathrm{m}$ in diameter. Immunoreactivity to progesterone, androstenediol and estradiol, varied in the different parts of the ovary and follicular cells. The progesterone antibody appeared clearly labelled in the theca interna of the growing follicle and increased in the granulosa; the androgen antibody was continuously weak and diffuses in all follicles; the estradiol labelling appeared weak and diffuse in preantral follicles then increased in antral follicles in both theca and granulosa or only in granulosa. In antral follicles, estradiol label was clearly localized in granulosa cells and totally devoid in theca cells. In Psammomys ovary, labels of hormone were diffuse or localized, weak or intense in the theca and or in the granulosa according to the follicle size.
\end{abstract}

Key words: morphometry, immunohistochemistry, steroidogenesis, ovarian follicles, rodents

\section{Introduction}

Ovaries consist of follicles as basic functional units. The follicle plays a major role in the dual function of the ovary, gametogenesis (oocyte maturation and ovulation), and hormonogenesis (sexual steroids and peptidic reproductive hormones). Ovarian sex steroid hormones, estrogen and progesterone, have crucial effects on female reproductive functions such as the development and maturation of reproductive organs, the appearance of normal cycles and provide the proper environment for the transport of gametes and nidation. Those steroid hormones are required for endocrine and

Correspondence: A. Boubekri, Université des Sciences et de la Technologie Houari Boumédiene, Faculté des Sciences Biologiques, Laboratoire de Recherche sur les Zones Arides. Bab Ezzouar 132 El Alia 16100 Algiers, Algeria; e-mail: boubekri_a@yahoo.fr local regulation at different levels of the reproductive system. In a central level, steroids may act directly on the pituitary or indirectly on the hypothalamus, and their action can be positive or negative, depending on the model system and physiological state [1-5]. Growth of ovarian follicles involves proliferation and differentiation of granulosa and theca cells [6-8]. In the small antral follicle the granulosa cells are able to respond to FSH in many ways, including activation of the aromatase system, and induction of LH receptors [9]. In the antral follicle, both granulosa and thecal cell compartments contribute to steroid secretion and involve the interplay of progestins, androgens and estrogens [10]. Estrogens promote follicular development by potentiating granulosa cell expression of gonadotrophin receptors, steroidogenesis, and gap junction formation, and by inhibiting granulosa cell apoptosis; in addition, estrogens may be needed for corpus luteum formation and maintenance [11-13]. 
Estrogens are synthesized by the preovulatory follicle through a series of gonadotrophin-dependent events: LH stimulates thecal cells to synthesize androgens (androstenedione and testosterone) which are substrates for FSH-induced aromatization to estrogens in granulosa cells $[14,15]$. Progesterone and androgens also have intrafollicular effects on follicular growth and steroidogenesis. Local high concentrations of progesterone may enhance the gonadotropin stimulation of progesterone biosynthesis in granulosa and luteal cell, this positive autofeedback mechanism is believed to be important for the autonomy of luteal cell steroidogenesis [11]. In the rat, the preovulatory progesterone plays an important role to increase $\beta$-FSH mRNA levels as well as the release of LH and FSH during the normal preovulatory gonadotropin surge [16]. In the primate corpus luteum, there are gonadotrophinstimulated, progesterone-dependent processes that promote luteotrophic and suppress luteolytic pathways [17]. Estradiol and progesterone act in synergy on LH secretion, an estradiol-induced increase in the sensitivity of the central nervous system to the negative feedback action of progesterone [18]. Androgens are products of progestogen metabolism, intermediates in oestrogen biosynthesis and local regulators of ovarian function, essentially by paracrine and autocrine regulation of follicular maturation and atresia $[19,20]$. In the rat ovarian follicles, theca provides the androgen precursor needed for follicular $17 \beta$-estradiol synthesis [21].

The aim of this work was to study the reproductive function of the sand rat, Psammomys obesus, in order to perform breeding laboratory. Indeed, this species constituted a model for studying several metabolic disorders when confined to standard laboratory diet, Psammomys develops diabetes [22,23] and other pathology $[24,25]$. In the male, different studies were already published [26-28]. In the female, the estrous cycle was characterized [29], in the gonad the histological aspect was published [30], the histological and cytological seasonal variations of the reproductive tract were studied [31]. To study normal ovarian function, during the reproductive period (from autumn to late spring), immunohistochemical methods was initiated $[20,30]$ to visualise steroid hormones. In the present study we have examined the relationship between the cellular localization of steroid hormones within the growing follicles in Psammomys obesus ovaries.

\section{Materials and methods}

Animals. The sand rat, Psammomys obesus Cretzschmar, 1828, is a diurnal rodent. This gerbillidae living in desert areas [32] was live trapped in Beni-Abbes region: $30^{\circ} 7^{\prime} \mathrm{N}-2^{\circ} 10^{\prime} \mathrm{W}$, of North Occidental Algerian Sahara. Psammomys is strictly submitted to Chenopodiacae (low-calorie salt bush rich in salt and water [33]. In laboratory, animals were housed under conditions of temperature and photoperiod corresponding to the natural environment and were fed with plants directly from the place of capture. The sex of animals was determined and females were isolated in individual cages. Only sexually mature, non-pregnant females were used.

Methods. Estrous cycles were monitored by daily vaginal smears. Three females were killed at each phase of the cycle [34]. In order to proceed to histological and immunohistological studies, ovaries were removed and immersion-fixed in Bouin's solution or in $4 \%$ paraformaldehyde in phosphate buffered saline solution (PBS, Sigma $\mathrm{pH}=7.4 ; 0.01 \mathrm{M})[35,36]$. Some ovaries were frozen in liquid nitrogen and preserved at $-70^{\circ} \mathrm{C}$ for next studies. After fixation, tissue samples were rinsed and then stored in $70 \%$ alcohol before processing and embedding into paraffin wax (Merck, Germany) using standard procedures. Serial sections, $5 \mu \mathrm{m}$ thickness, were cut (Leitz vertical microtome) and mounted on normal or Super Frost glass slides.

Histology. After dewaxed and re-hydrated through a graded ethanol series $(100 \%, 95 \% \& 70 \%)$ and washed in distilled water, topographical colorations were carried out by Heindenhain's azan or Masson's trichroma. The follicles were classified in healthy or atretic ones, according to their morphological and histological evolutional aspect [37-41]. Primary follicle has one layer of cuboidal granulosa cells, including those follicles containing a mixed layer of flattened and cuboidal granulosa cells because these belong to the growing pool of follicles in rodents; in secondary follicle, the oocyte is surrounded with two layers of granulosa cells; preantral follicle was distinguished by the presence of more than two layers of granulosa cells, without any cavity; and the antral follicles were the larger ones with a fluid-filling the unique cavity.

Immunohistochemistry. The optimal conditions for the immunohistological application to our biological material was previously presented [42]. The kit used is the LSAB 2 System, Peroxidase DAKO (Biomeda Staining Kit): an indirect immunohistochemistry method using streptavidin-biotin complex that allows amplification of marking. After dewaxing and re-hydrading, the sections were washed in PBS (Sigma $\mathrm{pH}=7.4 ; 0.01 \mathrm{M}$ ) and incubated in 3\% hydrogen peroxide for 5 minutes at room temperature to quench endogenous peroxidase, than rinsed in PBS $(3 \times 5$ minutes $)$.

Sections were incubated with the primary antibodies, 30 minutes at room temperature or over night at $4^{\circ} \mathrm{C}$, in a humid environment. Primary antibodies were: Polyclonal Rabbit anti-progesterone antibody (Biomeda or AbCys S.A.), Rabbit Polyclonal antiandrogen (Biomeda), Rabbit anti-estradiol Polyclonal antibody (Biomeda or Chemicon International, Inc.), and than rinsed three times for 5 minutes in PBS. The secondary biotinyled antibody was applied against the primary antibody during 30 minutes at ambient temperature, followed by washing in PBS. Then labelled streptavidine-peroxidase was applied during 30 minutes. The enzymatic reaction was visualised using substrate-chromogen solution: Amino-Ethyl-Carbazole (AEC) (from Vector Laboratories) or Diaminobenzidine (DAB) (DakoCytomation Ltd, Ely, UK or Roche) during 10-15 minutes at ambient temperature. Some sections were post-stained with aqueous hematoxylin to enhance the contrast and mounted in aqueous medium (Crystal mount).

Control staining. In negative controls, PBS was substituted for primary antibody in the first reaction [43].

Ovarian follicles analysis. The ovarian sections were viewed and examined by light microscopy, at different magnifications, microphotographs were taken at the same time using a Carl Zeiss (Germany) photomicroscope. Morphometric studies were performed according to $[39,40]$, follicle diameter was measured in the largest cross-section that showed the nucleolus by taking the average of both the two perpendicular diameters of each follicle. Values are presented as the minimum-maximum or as the means \pm SEM. Immunohistochemical staining was assessed using a semi quantitative inten- 

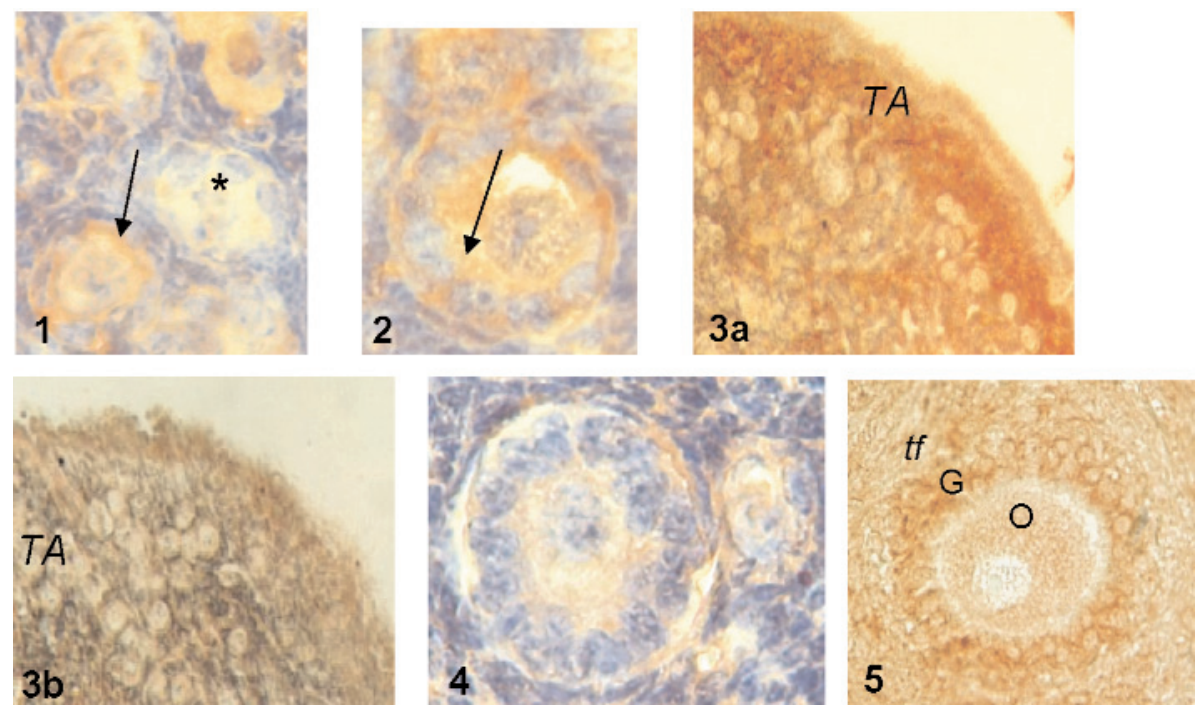

Fig. 1. Primordial follicles in ovarian sand rat. The follicles present no $(*)$ or low labelling (arrow) for different antibody: antiprogesterone, antiandrostenediol and antiestradiol were weakly expressed. Streptavidin-Biotin method, Mayer's haematoxylin post-staining (original magnification $\times 1000$ ). Fig. 2. Intermediary follicles with progesterone, androstenediol and estradiol low positive immunostaining. StreptavidinBiotin method, Mayer's haematoxylin post-staining (original magnification $\times 1000$ ). Fig. 3. Hormonal environment of primordial follicles in ovarian sand rat. (a) The tunica albuginea (TA) expresses positive antibody estradiol and anti-progesterone Streptavidin-Biotin method, Mayer's hematoxylin post-stain (original magnification $\times 200$ ); (b) Marking negative antibody testosterone. Streptavidin-Biotin method, Mayer's haematoxylin post-staining (original magnification $\times 200$ ). Fig. 4. Primary follicles in ovarian sand rat. These follicles present low immunostaining for different steroids hormones studied. Streptavidin-Biotin method, Mayer's haematoxylin post-staining (original magnification $\times 570$ ). Fig. 5. Small preantral follicles in ovarian sand rat: with undifferentiated theca folliculi $(\mathrm{tf})$; the granulosa $(\mathrm{G})$ was clearly immunopositive with estradiol antibody; oocyte $(\mathrm{O})$. Streptavidin-Biotin method (original magnification $\times 500$ ).

sity estimation: no labelling: -, low labelling: +, important labelling: ++ , very important labelling: +++ .

\section{Results}

During the ovarian cycle of Psammomys obesus, different stages of folliculogenesis have been observed. The follicle grows from primordial to preovulatory follicle; the differentiation of both granulosa and theca cells, the formation of the antrum, cumulus oophorus and corona radiata occurred normally. Steroid activities were analysed using immunohistochemical techniques. Estrogen, androgen and progesterone hormones were visualized in the different compartments of the ovary. In this part of the study, the labelling of steroids hormones was examined thought the follicular type cells and the growing size of follicles.

Observed at the periphery of the cortex, the diameter of primordial follicles varied from 17 to $20 \mu \mathrm{m}$, and the oocyte from 11 to $15 \mu \mathrm{m}$. Some follicles did not present any detectable label for different hormones studied, other presented only a low labelling for oestradiol and androstenediol, the lowest labelling was for progesterone (Fig. 1). In intermediary follicles (with both flattened and cuboidal follicular cells), progesterone, androstenediol and estradiol were weakly labelled (Fig. 2). The tunica albuginea, showed a positive labelling with both anti-estradiol and anti-progesterone (Fig. 3a) but it was not labelled with an anti-testosterone (Fig. 3b).

Two types of primary follicles, were distinguished: the smallest, with a total diameter of $27.5 \mu \mathrm{m}$ in average, containing an oocyte that can reach $16.3 \mu \mathrm{m}$ and the largest with an average diameter of $63.5 \mu \mathrm{m}$, the oocytes reaching $38.5 \mu \mathrm{m}$ in average diameter. This enlargement was associated with the oocyte maturation and growth process; in these follicles, weak immunostainings were observed for the different hormones (Fig. 4).

The Secondary follicles with two layers of granulosa cells were about $66 \pm 5.75 \mu \mathrm{m}$. Many small preantral follicles appeared surrounded by some stromal cells, the undifferentiated theca folliculi. In preantral follicles without antrum, and with an undifferentiated theca folliculi, a mitotic activity affected the ganulosa cells. The average diameter of those follicles was $245 \pm 15 \mu \mathrm{m}$. The granulosa was clearly labelled with estradiol antibody (Fig. 5). In the largest healthy preantral follicles, the theca folliculi differentiated into theca interna and theca externa. In the theca interna, the presence of progesterone was revealed with an obvious immunostaining; granulosa appeared weakly marking, the oocyte was slightly labelled (Fig. 6). Androstenediol was diffuse and was weakly labelled. Weak and uniform estradiol labelling, was situated between the theca and the granulosa in numerous preantral follicles. The diameter of the 
Table 1. Immunostaining variations of steroids localization and labeling intensity in Psammomys obesus ovarian growing follicles. (no labelling: -, low labelling: +, important labelling: ++, very important labelling: +++ ).

\begin{tabular}{|l|c|c|c|}
\hline \multicolumn{1}{|c|}{ Follicle types } & Primordial follicles & Intermediary follicles & Primary follicles \\
\hline Progesterone & $-/+$ & + & + \\
Androstenediol & $-/+$ & + & + \\
Estradiol & $-/+$ & + & + \\
\hline
\end{tabular}

\begin{tabular}{|l|c|c|c|c|c|c|}
\hline \multicolumn{1}{|c|}{ Follicle types } & \multicolumn{2}{|c|}{ Preantral follicles } & \multicolumn{2}{c|}{ Antral follicles } & \multicolumn{2}{c|}{ Large antral follicles } \\
\hline Follicule components & theca interna & granulosa & theca interna & granulosa & theca interna & granulosa \\
\hline Progesterone & +++ & + & +++ & + & +++ & ++ \\
Androstenediol & + & + & + & - & + & $+/+$ \\
Estradiol & + & $+/++$ & + & + & $++/+++$ \\
\hline
\end{tabular}
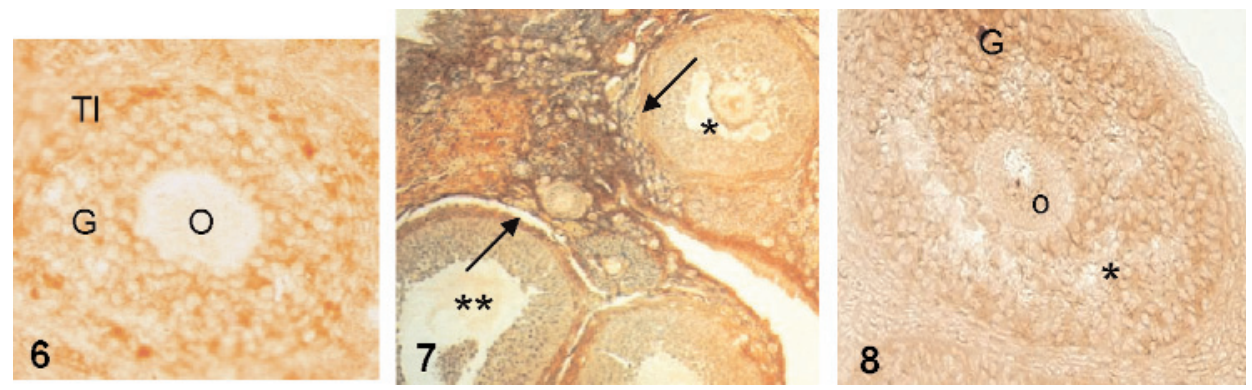

Fig. 6. Large preantral follicle in ovarian sand rat. Theca interna (TI) was well differentiated and expressed an obvious label of progesterone, the granulosa (G) appeared weakly positive. O: ovocyte. Streptavidin-Biotin method (original magnification $\times 500$ ). Fig. 7 . Immunohistochemical localisation of progesterone in ovarian sand rat section. In follicles with scattered areas $(*)$ or unique antrum $(* *)$, progesterone immunostaining was clearly observed in the theca interna (arrow). The stroma was also clearly labelled. Streptavidin-Biotin method (original magnification $\times 70$ ). Fig. 8. Immunohistochemical localisation of oestradiol in ovarian sand rat section. In follicles with scattered areas, strong label of ostradiol appeared in the granulosa $(\mathrm{G})$. Streptavidin-Biotin method (original magnification $\times 200$ ).

follicles with scattered areas filled with follicular fluid was between $250 \mu \mathrm{m}$ and $300 \mu \mathrm{m}$. Progesterone immunostaining was clearly observed in the theca interna (Fig. 7); strong label to oestradiol appeared in the granulosa at this stage (Fig. 8).

The antral follicles have a unique fluid-filled cavity. At the pro-estrous of the cycle, the diameter of healthy antral follicles varied from $340 \mu \mathrm{m}$ to $480 \mu \mathrm{m}$. At estrous, during the late follicular development, the healthy largest preovulatory follicles reached about 514-520 $\mu \mathrm{m}$ in diameter. In small antral follicles, progesterone immunoreactivity was clearly observed in the theca interna; in the granulosa the label was still slight, it will increase with the developing antral follicles (Fig. 9). Androstenediol labelling cells was located in the theca interna and remained slightly diffuse in the granulosa of those follicles (Fig. 10). For the same dilution of estradiol (1/300) variable intensity appeared in different antral follicles or in the different compartments of the same follicle. The immunolabellings were clear and involved both granulosa and theca compartments in some antral follicles (Fig. 11a); in the theca interna the label was heterogeneous by the presence of no marking cells (Fig. 11b), these unstained cells could be undifferentiated or inactivated cells. In large antral follicles, with preovulatory features, the granulosa appeared also as an heterogeneous compartment: the label decreased from the peripheral granulosa that was
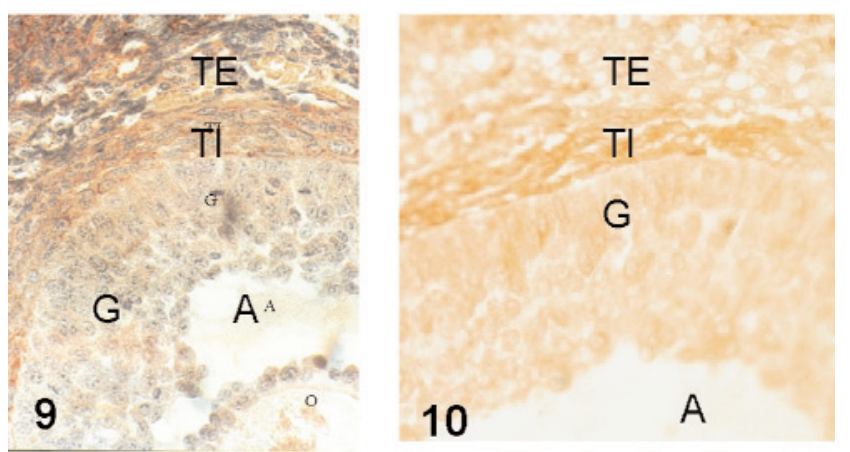

Fig. 10. Progesterone immunoreactivity in small antral follicles of ovarian sand rat. In small antral follicles, progesterone immunoreactivity was clearly observed in the theca interna; in the granulosa the label was still slight. TE: theca externa, TI: theca interna. G: granulosa, A: antrum. Streptavidin-Biotin method (original magnification $\times 500$ ). Fig. 11. Androstenediol labelling in antral follicles of ovarian sand rat. Androstenediol labelling cells were located in the thecal interna of antral follicles and remained slightly diffuse in the granulosa of those follicles. TE: theca externa, TI: theca interna. G: granulosa, A: antrum. Streptavidin-Biotin method (original magnification $\times 500$ ). 

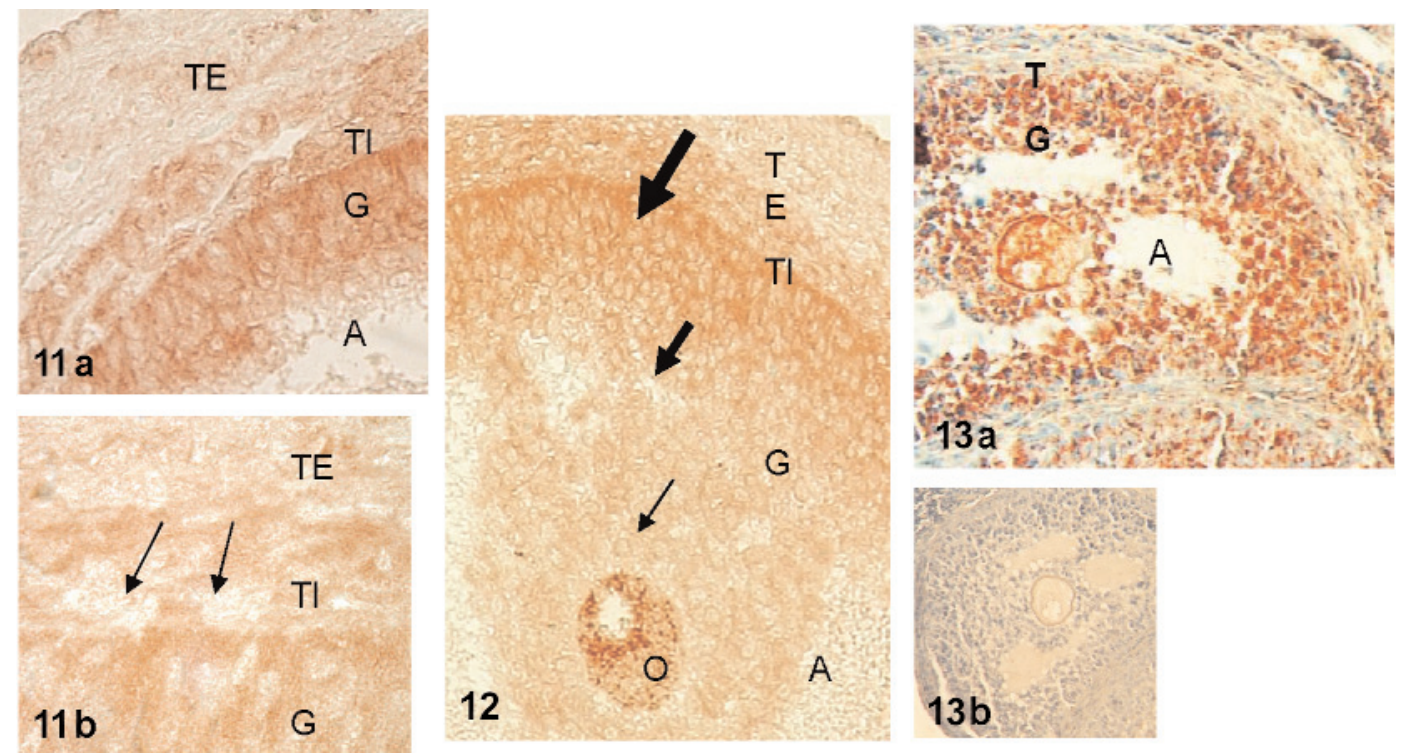

Fig. 11. Estradiol in antral follicles of ovarian sand rat. (a) Follicular wall of a healthy antral follicle immunostained with estradiol antibody: in some antral follicles the staining involve both granulosa $(\mathrm{G})$ and theca compartments. TI: theca interna, TE: theca externa, A: antrum. Streptavidin-Biotin method (original magnification $\times 500$ ). (b) In the theca interna the label was heterogeneous by the presence of no unlabelled cells (arrow). G: granulosa; TI: theca interna; TE: theca externa. Streptavidin-Biotin method (original magnification $\times 570$ ). Fig. 12. Estradiol in large antral follicles of ovarian sand rat. In large antral follicles, the granulosa $(G)$ appeared heterogeneous: the label decreased from the peripheral granulosa that was highly marked (large arrow), to the compact cumulus cell-oocyte complex when the cells become slightly labelled (thin arrow). TI: theca interna; TE: theca externa, O: ovocyte, A: antrum. Streptavidin-Biotin method (original magnification $\times 200$ ). Fig. 13 (a) Estradiol in different antral follicles of ovarian sand rat. In other antral follicles, significant immunoreactivity was observed only in the granulosa $(\mathrm{G})$, theca interna (TI) was clearly negative. A: antrum. Streptavidin-Biotin method, Mayer's haematoxylin post-staining (original magnification $\times 200$ ). (b) Negative immunocontrol by omission of the primary antibody. StreptavidinBiotin method, Mayer's haematoxylin counterstaining (original magnification $\times 70$ ).

highly marked, to the compact cumulus cell-oocyte complex when the cells become slightly labelled (Fig. 12). In other antral follicles, a significant immunoreactivity was observed only in the granulosa compartment, the theca interna remaining clearly negative (Fig. 13a); specificity of labelling was underscored by negative controls after omission of the primary antibody (Fig. 13b) (Table 1). During the growth of the ovarian Psammomys follicles, we observed that progesterone appeared in all growing follicles, and was clearly marked in theca and diffuse in granulosa until the antral follicles, that could expressed the initiation of the luteinising process in the healthy growing follicles. Androstenediol appeared diffuse in the follicles, intensity increased in the theca interna of antral follicles and shrinked in the granulosa. The estradiol showed extensive labelling in the layers of granulosa and theca cells belonging to advanced preantral and in growing small to large antral and preovulatory follicles. This steroid hormone seems to be involved in an autocrine and/or paracrine regulatory mechanism linked to growth and maturation of follicles.

\section{Discussion}

The development of ovarian follicles is a complex process characterized by the growth, differentiation (structural and functional) and maturation of follicle components: oocyte, granulosa and theca cells; this process involves interactions between endocrine factors and intraovarian regulators (sex steroids, growth factors and cytokines). In Psammomys obesus, the histomorphological process of folliculogenesis has been study [30], it appears similar to that described in other mammals. In this part, the stages of folliculogenesis, estimated by morphometrical changes and variations in size, were compared according to other rodents, it seems to be similar with slight differences. The mean size of Psammomys primary follicles appears greater than that of the wild type laboratory mice $(31 \pm 2 \mu \mathrm{m})$ [44]. The size of follicles sand rat with undifferentiated theca folliculi was smaller than those of laboratory rat $(<350 \mu \mathrm{m})$ [45] and also smaller for the large preantral follicles that differentiated theca folliculi $(350-$ $500 \mu \mathrm{m})$ [45], even with the Mongolian gerbil (280 $365 \mu \mathrm{m})$ [46] this observation could reflects a relatively early recruitment process. The litter antral follicles size is $320 \mu \mathrm{m}$, noticed in Mus musculus [47]; the preovulatory follicles size of Psammomys appear relatively smaller than that of other rodents: in Mus musculus is about 320 to $400 \mu \mathrm{m}$ [47], 645 to $647 \mu \mathrm{m}$ in the Hamster [48] and 810 to $855 \mu \mathrm{m}$ in Rattus rattus [49]; in the gerbillidae family, preovulatory follicles of Psammomys obesus appear greater than those of the 
Mongolian gerbil, Meriones unguiculatus $(480 \mu \mathrm{m})$ [46].

The steroidogenic pathway within the ovary gives rise to progestins, androgens and estrogens. In Psammomys obesus, the steroid activities were analysed by means of immunohistochemical techniques to localise the ovarian steroid hormones within the follicle and thought the growing follicles size. In ovarian primordial follicle, the progesterone inhibited the coordinated oocyte apoptosis required for primordial follicle assembly; progesterone and estrogen are involved in the control of primordial follicle assembly and the early follicular development [50]. In the largest preantral follicles, the morphologically differentiated theca interna cells have a strong immunostaining to progesterone antibody; according to Maggofin [51] the theca cells express an intracellular synthesis of progesterone reflecting the initiation of steroidegenesis process in the considering follicle. In developing antral follicles, progesterone immunoreactivity was observed in the granulosa, according to Kamada et al. [8] progesterone regulates the action of estrogen through the decrease of estrogen receptor and down regulation of its own receptor in granulosa cells. In the theca interna the progesterone labelling was continuously clear; this observation suggested that cells of theca become functional and contribute to progesterone secretion by the mature corpus luteum [52]. Indeed, Psammomys obesus corpus luteum secretes both estradiol and progesterone [30]. Androstenediol was diffuse and weakly labelled across the preantral follicles. In antral follicles labelling was mainly located in the theca interna; in the rat, this compartment is the site of follicular androgen production as precursor needed for follicular $17 \beta$-estradiol synthesis [53]. The androgen labeling remains slightly diffuse in the granulosa of all the antral follicles. This metabolite constituted a substrate for follicular $17 \beta$-estradiol synthesis $[53,54]$ and our results suggest a paracrine regulation of androgen in the follicle. Indeed, the theca cells stimulate follicle growth by granulosa cell mitosis through FSH-induced androgen receptor, and cause androgen-stimulated formation of FSH receptor [55]. In advanced preantral follicles, estradiol label was slight and uniform between theca and granulosa compartments, the labelling increased in antral follicles. The label expressed in theca cells would suggest the involvement of this component in biosynthesis of estradiol, as it is expressed in mouse and hamster theca cells which express aromatase [56] or in pigs [57]. If the estradiol observed in theca comes from granulosa, this feature reflects a paracrine regulation; indeed, estradiol causes an increase of androgen production by thecal cells and, contrarily, the suppression of progesterone production, throughout the 6-day culture period [58]. In other large antral follicles, a sig- nificant immunoreactivity was strictly localized in granulosa and absent in the theca interna. This could suggest a functional differentiation in the biosynthesis of estradiol; indeed, according to Matsuda et al. [56], aromatase is expressed in these cells in many rodents; elsewhere, these observations coincide with the data of Irian et al. and Tsafritri et al. [59,60] that described a maximal production of estradiol in the largest antral follicles.

\section{Conclusion}

To study the reproductive function of the sand rat, Psammomys obesus, the ovarian activity was examined. In this part, we followed the morphometrical developement during folliculogenesis and the relationship between the cellular localization of steroid hormones within the growing follicles. Progesterone, androstenediol and estradiol were visualised by immunohistochemistry. The labelling was diffuse or localised, weak or intense in the theca and or in the granulosa component according to the follicle size. Progesterone was diffuse between theca and granulosa in all follicles but was intense in theca than in granulosa. The androgen was continuously weak and diffuse in all follicles. Estradiol showed extensive labelling in the layers of granulosa and theca cells of advanced preantral and growing small antral follicles; in large ones significant immunoreactivity was strictly localized in granulosa and negative in the theca interna. To support our observations it is important to detect the expression of steroidogenic enzymes and precise the enzymatic content of the granulosa and theca cells during folliculogenesis by immunohistochemistry or in situ hybridation to featuring the steroidogenic activity in ovarian sand Rat.

Competing interests: The authors declare that they have no competing interests.

Authors' contribution: BA carried out the experiment and wrote the manuscript studies. TGS, FK and JME discussed the results and corrected the manuscript. All authors read and approved the final manuscript.

Acknowledgments: The authors would like to thank the technicians of the Unite de Recherche sur les Zones Arides (FSB) in Béni-Abbes for trapping the animals. Thanks to Dr J Estabel for advice on immunohistochemical methods and Ms. M.T. Laurent for there kindly assistance. Immunohistochemical part of this work was supported by Accord programme algéro-français 00 MDU 489 CMEP.

\section{References}

[1] Karsch FJ, Dierschke DK, Weick RF, Yamaji T, Hotchkiss J, Knobil E. Positive and negative feedback control by estrogen of luteinizing hormone secretion in the rhesus monkey. Endocrinology. 1973;92:799-804..

[2] Leung PC, Armstrong DT. Interactions of steroids and gonadotropins in the control of steroidogenesis in the ovarian follicle. Ann Rev Physiol. 1980;42:71-82. 
[3] Mahesh VB, Muldoon TG. Integration of the effects of estradiol and progesterone in the modulation of gonadotropin secretion. J Steroid Biochem. 1987; 27:665-75.

[4] Danforth DR, Elkind-Hirsch K, Hodgen GD. In vivo and in vitro modulation of gonadotropin-releasing hormone metabolism by estradiol and progesterone. Endocrinology. 1990;127:319-324.

[5] Shupnik MA. Gonadotropin gene modulation by steroids and gonadotropin-releasing hormone. Biol Reprod. 1996;54:279286.

[6] Rao MC, Midgley AR, Richards JS. Hormonal regulation of ovarian cellular proliferation. Cell. 1978;14:71-8.

[7] Kol S, Adashi EY. Intraovarian factors regulating ovarian function. Curr Opin Obstet Gynecol. 1995;7:209-13.

[8] Kamada M, Yamano S, Irahara M, Aono T. Estrogen, progesterone--biosynthesis, receptor and action. Nippon Rinsho. 1997;55:2865-70.

[9] Channing CP, Schaerf FW, Anderson LD, Tsafriri A. Ovarian follicular and luteal physiology. Int Rev Physiol. 1980;22:117-201.

[10] Gore-Langton RE, Armstrong DT. Follicular steroidogenesis and its control. In: Knobil E, Neill J, eds. The Physiology of Reproduction. 1994, 2nd ed. New York: Raven Press, Ltd.;1:571-627.

[11] Kessel B, Liu YX, Jia XC, Hsueh AJ. Autocrine role of estrogens in the augmentation of luteinizing hormone receptor formation in cultured rat granulosa cells. Biol Reprod. 1985;32:1038-50.

[12] Hsueh AJ. Paracrine mechanisms involved in granulosa cell differentiation. Clin Endocrinol Metab. 1986;15:117-34.

[13] Rosenfeld CS, Wagner JS, Roberts RM, Lubahn DB. Intraovarian actions of oestrogen. Reproduction. 2001;122: 215-26.

[14] Dorrington JH, Bendell JJ, Khan SA. Interactions between FSH, estradiol-17 beta and transforming growth factor-beta regulate growth and differentiation in the rat gonad. $J$ Steroid Biochem Mol Biol. 1993;44:441-7.

[15] Hillier SG, Whitelaw PF, Smyth CD. Follicular oestrogen synthesis: the 'two-cell, two-gonadotrophin' model revisited. Mol Cell Endocrinol. 1994;100:51-54.

[16] Brann DW, O'Conner JL, Wade MF Zamorano PL, Mahesh VB. Regulation of anterior pituitary gonadotropin subunit mRNA levels during the preovulatory gonadotropin surge: a physiological role of progesterone in regulating LH-beta and FSH-beta mRNA levels. J Steroid Biochem Mol Biol. 1993;46:427-37.

[17] Stouffer RL. Progesterone as a mediator of gonadotrophin action in the corpus luteum: beyond steroidogenesis. Hum Reprod Update. 2003;9:99-117

[18] Goodman RL, Bittman EL, Foster DL and Karsch FJ. The endocrine basis of the synergistic suppression of luteinizing hormone by estradiol and progesterone. Endocrinology. 1981;109:1414-1417.

[19] Hillier SG, Tetsuka M. Role of androgens in follicle maturation and atresia. Baillieres Clin Obstet Gynaecol. 1997;11:249-60.

[20] Tetsuka M, Hillier SG. Differential regulation of aromatase and androgen receptor in granulosa cells. J Steroid Biochem Mol Biol. 1997;61:233-9.

[21] Fortune JE, Armstrong DT. Androgen production by theca and granulosa isolated from proestrous rat follicles. Endocrinology. 1977;100:1341-1347.

[22] Schmidt-Nielsen K, Haines HB, Hackel DB. Diabetes Mellitus in the Sand Rat Induced by Standard Laboratory Diets. Science. 1964;143:689-690.

[23] Ziv E, Kalman R, Hershkop K, Barash V, Shafrir E, Bar-On $\mathrm{H}$. Insulin resistance in the NIDDM model Psammomys obesus in the normoglycaemic, normoinsulinaemic state. Diabetologia. 1996;39:1269-75.
[24] Silberberg R. The vertebral column of diabetic rat (Psammomys obesus). Exp Cell Biol. 1988;56:217-220.

[25] Maislos M, Medvedovskv V, Sztarkier I, Yaari A, Sikuler E. Psammomys obesus (sand rat), a new animal model of non-alcoholic fatty liver disease. Diabetes Res Clin Prac. 2006;72:1-5.

[26] Khammar F, Brudieux R. Seasonal changes in plasma testosterone concentrations in response to administration of hCG in a desert rodent, the sand rat (Psammomys obesus) $J$ Reprod Fert. 1989;85:171-175.

[27] Khammar F, Brudieux R. Seasonal changes in plasma concentrations of gonadotropins and in the responsiveness of the pituitary and testis to GnRF in a desert rodent, the sand rat (Psammomys obesus). Reprod nutr dev. 1991;31:675682.

[28] Gernigon T, Berger M, Lecher P. Seasonal variations of ultrastructure and production of androgen-dependent proteins in the seminal vesicles of a Saharian rodent (Psammomys obesus). J Endocrinol. 1994;142:37-46.

[29] Boubekri A, Khammar F, Gernigon T. The oestrous cycle of Psammomys obesus, (Rodentia, Gerbillidae) living in algeria. In Proceeding of the Fifth Rodens \& Spatium, Biodiversity and adaptation. Zaime A. (Ed.), Rabat, Maroc; 20-24 March 1996:149-154.

[30] Boubekri A, Gernigon-Spychalowicz T, Khammar F, Exbrayat JM. Histological and immunohistological aspects of the ovarian cycle of the algerian wild sand rat, Psammomys obesus Cretzschmar, 1828. Folia Histochem Cytobiol. 2007;45 (Suppl 1):41-49.

[31] Boubekri A. Etude histologique et cytologique des variations saisonnieres de l'appareil reproducteur femelle d'un rongeur déserticole diurne, le rat des sables, Psammomys obesus Cretzschmar, 1828, dans son biotope. These de Magister, FSB, USTHB, Alger; 1998.

[32] Petter F. Répartition géographique et écologique des rongeurs désertiques (du Sahara occidental a l'Iran oriental). Mammalia. 196;25: № Spécial.

[33] Daly M, Daly S. On the feeding ecology of Psammonys obesus (Rodentia, Gerbillidae) in the Wadi Saoura, Algeria. Mammalia. 1973;37:546-561.

[34] Nelson JF, Felicio LS, Randall PK, Sims C, Finch CE. A longitudinal study of Estrous cyclicity in Aging C57BL/6J Mice: I. Cycle frequency, length and vaginal cytology. Biol Reprod. 1982;27:327-339.

[35] Martoja R, Martoja-Pierson M. Initiation aux techniques de l'Histologie Animale. Masson, Paris, 1967, 345p.

[36] Exbrayat JM. Méthodes classiques de visualisation du génome en microscopie photonique. In: Techniques de visualisation moléculaire. Ed: TEC \& DOC, EM inter, Paris, 182 p.

[37] Pederson T, Petters H. Proposal for a classification of oocytes and follicles in the mouse ovary. $J$ Reprod Fert. 1968;17:555557.

[38] Hage AJ, Groen-Klevant AC, Welschen R. Follicle growth in the immature rat ovary. Acta Endocrinol. 1978;88:375382.

[39] Gosden RG, Telfer E, Faddy MJ, Brook DJ. Ovarian cyclicity and follicular recruitment in unilaterally ovarietomyzed mice. J Reprod Fert. 1989;87: 257-264.

[40] Gougeon A. Initiation of ovarian follicular growth: few facts and many hypothesis. In: The ovary: regulation, dysfunction and treatment. Filicori M, Flamigni C, eds Amsterdam: Elsevier Sciences, 1996;3-12

[41] Durlinger AL, Gruijters MJ, Kramer P, Karels B, Ingraham HA, Nachtigal MW, Uilenbroek JT, Grootegoed JA, Themmen AP. Anti-Mullerian hormone inhibits initiation of primordial follicle growth in the mouse ovary. Endocrinology. 2002;143:1076-1084

[42] Boubekri A, Gernigon T, Khammar F, Exbrayat JM. Approche immunohistochimique de l'ovaire du rat des sables 
du sud ouest algérien, en période de reproduction. Rev Fr Histotechn. 2004;17:21-29.

[43] Boenisch T. Controls. In: Immunochemical staining methods. Boenisch T, Farmilo AJ, Stead RN ed Naish SJ, DAKO Corporation, California, USA, 1989, pp 41.

[44] Balla A, Danilovich N, Yang Y, Sairam MR. Dynamics of Ovarian Development in the FORKO Immature Mouse: Structural and Functional Implications for Ovarian Reserve. Biol Reprod. 2003;69:1281-1293.

[45] D'agostino J, Woodruff TK, Mayo KE, Schwartz NB. Unilateral ovariectomy increases inhibin messenger ribonucleic acid levels in newly recruited follicles. Endocrinology. 1989;124:310-317.

[46] Norris ML, Adams CE. Sexual development in the Mongolian gerbil, Meriones unguiculatus, with particular reference to the ovary. J Reprod fert. 1974;36: 245-248.

[47] Allen E. The estrous cycle in the mouse. Am J Anat. 1922;30: 297-371.

[48] Roy SK, Greenwold GS. Mediation of FSH action on Follicular Deoxyribonucleic Acid synthesis by Epidermal Growth Factor. Endocrinology. 1991;129:1903-1908.

[49] Sing S, Gouraya SS. Follicular growth pattern in the House Rat (Rattus rattus). Eur J Morphol. 1993;31: 257-267.

[50] Kezele P, Skinner MK. Regulation of Ovarian Primordial Follicle Assembly and Development by Estrogen and Progesterone: Endocrine Model of Follicle Assembly. Endocrinology. $2003 ; 144: 3329-3337$

[51] Maggofin DA. Regulation of differentiated functions in ovarian theca cells. Sem Reprod Endocrinol. 1991;9:321-331.
[52] Richards JS, Hedin L, Caston L. Differentiation of rat ovarian thecal cells: evidence for functional luteinization. Endocrinology. 1986;118: 1660-1668.

[53] Fortune JE, Armstrong DT: Androgen production by theca and granulosa isolated from proestrous rat follicles. Endocrinology. 1977;100:1341-1347

[54] Roberts AJ, Skinner MK. Estrogen regulation of thecal cell steroidogenesis and differentiation: thecal cell-granulosa cell interactions. Endocrinology. 1990;127:2918-29

[55] Tajima K, Orisaka M, Mori T, Kotsuji F. Ovarian theca cells in follicular function Reprod Biomed Online. 2007;15: 591-60.

[56] Matsuda H, Fujita H, Ishimura K. Immunocytochemical localisation of aromatase in ovaries of some rodents, cow and human. Acta Histochem Cytochem. 1994;17:311-322.

[57] Tonetta SA, DeVinna RS, diZerega GS. Modulation of porcine thecal cell aromatase activity by Humain Chorionic Gonadotropin, Progesterone, Estradiol-17 $\beta$, and Dihydrotestosterone. Biol. Reprod. 1986;35:785-791.

[58] Roberts AJ, Skinner MK. Estrogen regulation of thecal cell steroidogenesis and differentiation: thecal cell-granulosa cell interactions. Endocrinology. 1990;127:2918-29.

[59] Irian F, Hodgen G.D. Mechanism of ovulation. Endocrinol. Metab. Clinics. North America. 1992;21:19-36.

[60] Tsafriri A, Adashi E.Y. Local nonsteroidal regulators of ovarian function. In Physiology of Reproduction. Second edition. E. Knonil and J.D. Neill- Raven press, Ltd New York; 1994, pp 817-860. 